\title{
PREDICTION OF FUEL TEMPERATURE OF AP1000 DUE TO THE FORMATION OF CRUD AND OXIDE LAYER
}

\author{
Muhammad Darwis Isnaini, M. Subekti, Geni Rina Sunarya \\ Center for Nuclear Reactor Technology and Safety, BATAN, \\ Puspiptek Area Building No. 80 Serpong, Tangerang Selatan, 15310 Indonesia \\ Email: darwis@batan.go.id \\ Diterima editor: 12 Mei 2017 \\ Diperbaiki: 2 Juni 2017 \\ Disetujui untuk publikasi: 5 Juni 2017
}

\begin{abstract}
PREDICTION OF FUEL TEMPERATURE OF AP1000 DUE TO THE FORMATION OF CRUD AND OXIDE LAYER. An analysis to predict the fuel temperature due to crud and oxide layer formed on the hot sub-channel cladding surface of AP1000 reactor has been performed. During reactor operation, the heat transfer and cooling process occur on the fuel cladding surface. During the heat exposure process, an oxide layer and crud are formed on the cladding surface. The decrease of heat transfer performance will increase the fuel and cladding temperatures. Therefore, the effect of fuel temperature increase during the heat exposure process has to be analyzed. The analysis was conducted for nominal power of 3400 MWt using COBRA-EN code, by varying the modular oxide thickness of $0,20,40,60,80,100$ and 120 $\mu \mathrm{m}$, crud thickness of 0,10 and $20 \mu \mathrm{m}$ and black oxide thickness of $0,10,20,30$ and $40 \mu \mathrm{m}$. For full cycle hot sub-channel condition, the combination of crud thickness of $20 \mu \mathrm{m}$ and modular oxide thickness of $115 \mu \mathrm{m}$ give prediction of the peak fuel center line temperature and the peak cladding surface temperature of $1870.73^{\circ} \mathrm{C}$ and $609.40^{\circ} \mathrm{C}$, respectively. However, the oxide layer is predicted only formed on hot sub-channel during BOC (about $40 \%$ of full cycle). The results show that the prediction of the peak fuel center line temperature and the peak cladding surface temperature are $1713.18^{\circ} \mathrm{C}$ and $451.87^{\circ} \mathrm{C}$, respectively. Compared to the normal and fresh fuel conditions, the peak fuel center line temperature and the peak cladding surface temperature increase by $6.53 \%$ and $29.86 \%$, respectively.
\end{abstract}

Keywords: Fuel temperature, Crud, Oxide layer, COBRA-EN, AP1000

\section{ABSTRAK}

PREDIKSI TEMPERATUR BAHAN BAKAR AP1000 AKIBAT ADANYA BENTUKAN ENDAPAN DAN LAPISAN OKSIDA. Telah dilakukan penelitian untuk memprediksi temperatur bahan bakar akibat terbentuknya endapan dan lapisan oksida pada permukaan kelongsong sub kanal panas dari reaktor AP1000. Selama operasi reaktor, proses pemindahan kalor and pendinginan terjadi pada permukaan kelongsong. Selama proses pemaparan kalor, endapan dan lapisan oksida terbentuk pada permukaan kelongsong. Berkurangnya pemindahan kalor akan berakibat pada kenaikan temperatur bahan bakar dan kelongsong. Oleh karena itu, dampak kenaikan temperatur bahan bakar selama proses pemaparan kalor perlu dianalisis. Analisis dilakukan pada kondisi daya nominal sebesar 3400 MWt dengan menggunakan kode COBRA-EN, untuk variasi tebal lapisan oksida modular 0, 20, 40, 60, 80, 100 dan $120 \mu$ m, variasi tebal endapan 0, 10 dan $20 \mu \mathrm{m}$, dan variasi tebal lapisan oksida hitam 0, 10, 20, 30 dan $40 \mu \mathrm{m}$. Untuk kondisi sub kanal panas selama siklus penuh, kombinasi tebal $20 \mu \mathrm{m}$ dan tebal lapisan oksida modular $115 \mu m$ memberikan prediksi temperatur puncak sumbu bahan bakar dan temperatur puncak permukaan kelongsong masing-masing sebesar $1870,73^{\circ} \mathrm{C}$ dan $609,40^{\circ} \mathrm{C}$. Akan tetapi, lapisan oksida diprediksi hanya terjadi pada sub kanal panas selama awal siklus (sekitar 40\% waktu satu siklus penuh). Hasil perhitungan menunjukkan bahwa prediksi temperatur puncak sumbu bahan bakar dan temperatur puncak permukaan kelongsong masing-masing sebesar $1713,18^{\circ} \mathrm{C}$ dan $609,40^{\circ} \mathrm{C}$. Dibandingkan dengan temperatur bahan bakar pada kondisi segar dan normal, maka temperatur puncak sumbu bahan bakar dan temperatur puncak permukaan kelongsong mengalami kenaikan masing-masing sebesar 6,53\% dan $29,86 \%$.

Kata kunci: Temperatur bahan bakar, endapan, lapisan oksida, COBRA-EN, AP1000. 


\section{INTRODUCTION}

When Light Water Reactor (LWR) is operated, the heat is generated by nuclear fission in the solid cylindrical pellets. Then, the heat is removed from the fuel by the coolant water through the outer cladding. The cladding is made of a zirconium alloy (i.e. Zircaloy-2 and Zircaloy-4). Zirconium alloy has been used as fuel cladding owing to its low neutron absorption cross section area, proper mechanical properties at high temperature, and high corrosion resistance [1]. The cladding surface is smooth and clean. However, a very thin oxide layer $\mathrm{ZrO} 2$ (about 2-5 nm of thickness) always presents due to oxidation of air [2]. At the same time, there are heat transfer and cooling process on the fuel cladding surface. During exposure to coolant at low temperature for long periods, or high temperature for short periods, an oxide layer and crud are formed on the cladding surface of the fuel rod. At nominal power, the fuel cladding temperature is about $300^{\circ} \mathrm{C}$, however higher temperatures could be reached during transient [3]. For transient condition, retention of maximum ductility for about $17 \%$ of oxidized cladding sets the fuel cladding peak temperature of $1204^{\circ} \mathrm{C}$ in the loss of coolant accident (LOCA). This acceptance criteria is related to cladding embrittlement [4]. As a comparison, in Supercritical Water Cooled Reactor (SCWR), the temperature of hot spot on the fuel cladding were designed exceeds $600^{\circ} \mathrm{C}$ at normal operations [5]. For zircaloy-4, the growth strain significantly increases after transient stage at a fluence of around $1.0 \times 1025 \mathrm{n} / \mathrm{m} 2$, at temperature of $280^{\circ} \mathrm{C}[6]$.

Zirconium oxide (oxide layer) and crud will be formed on zircaloy-4 cladding surface throughout reactor operation which is about 12-18 months. The oxidation reaction is described as:

$$
\mathrm{Zr}+2 \mathrm{H}_{2} \mathrm{O} \rightarrow \mathrm{ZrO}_{2}+2 \mathrm{H}_{2}
$$

This oxide layer product has a poor thermal conductivity, therefore fuel temperature increases during operation. There are two types of oxide layer employed i.e., modular oxide and black oxide. The characteristics of these two layers were reported in high temperature. The modular oxide thermal conductivity was higher than black oxide. At temperature less than $1200^{\circ} \mathrm{C}$, it was found that the maximum modular oxide thickness was around $113 \mu \mathrm{m}$, whereas black oxide thickness was around $20 \mu \mathrm{m}$. The values of thermal conductivity of modular oxide varied from 1.0 $\mathrm{W} / \mathrm{m}^{\circ} \mathrm{C}$ at $400^{\circ} \mathrm{C}$ to $1.6 \mathrm{~W} / \mathrm{m}^{\circ} \mathrm{C}$ at $1200^{\circ} \mathrm{C}$. However, the values of thermal conductivity of black oxide are in the range $0.13 \mathrm{~W} / \mathrm{m}^{\circ} \mathrm{C}$ to $0.86 \mathrm{~W} / \mathrm{m}^{\circ} \mathrm{C}$ for the same temperature [3]. The other fuel rod performance evaluation is to analyze the corrosion characteristic which was conducted by using thermal conductivity of the crud that vary from 0.8648 to $0.4324 \mathrm{~W} / \mathrm{m}^{\circ} \mathrm{C}$ [7].

Since crud and oxide layer have low thermal conductivity, thus heat transfer process from fuel rod through the cladding by primary coolant will be hindered. Consequently, due to the crud and oxide layer, the decreasing of heat transfer will effect on the increasing of fuel and cladding temperatures, especially the cladding surface and the peak center line temperature. Therefore, it is important to predict the fuel and cladding temperature that are influenced by crud and oxide layer formed on cladding surface of AP1000 fuel rod. The prediction was conducted using COBRA-EN code [8]. Some researchers have used COBRA-EN code for thermal-hydraulics analysis on radial and axial power fluctuation [9], comparison analysis using fixed and temperature function of thermal conductivity [10], validation of SIMBAT-PWR [11], optimizing gap conductance [12], capability test for VVER $[13,14]$ as well as core and sub-channel analysis of VVER $[15,16]$.

In case of the analysis using fuel heating model, COBRA-EN code could only be used for fixed value of thermal conductivity. The oxidation occurs only on the cladding of the hot rod. It can cause the increasing of flow resistance in the sub-channel around it. Fuel model of AP1000 was taken. In AP1000, the hot sub-channel has total peaking factor of 2.60 or equal to $48.88 \mathrm{~kW} / \mathrm{m}$ of peak linear power.

This research aims to determine the influence of crud and oxide layer against the subchannel thermal-hydraulic parameters of AP1000. The analysis includes the effect on peak fuel center line temperature as well as peak cladding surface temperature. This study focuses on the variation of crud and oxide layer thickness on fuel cladding surface of AP1000, which is conducted using COBRA-EN code. The AP1000 core consists of 157 fuel assemblies, and each fuel assembly consists of 264 fuel rods. The reactor has output power of $3400 \mathrm{MWt}$ and effective flow rate for 
heat transfer of $48,443.7$ ton/hr $[9,11]$. This research accomplishes the previous research about thermal-hydraulics analysis on radial and axial power fluctuation [9] as well as analysis using fixed and temperature function thermal conductivity [10].

\section{THEORY}

The prime objective of any safety action in a nuclear power plant is maintaining the nuclear fuel cladding's structural integrity which protects radioactive fuel from undergoing nuclear fission [17]. Zirconium alloys are main structural material of fuel cladding, due to the combination of excellent corrosion resistance, good neutron penetration and suitable mechanical properties [18]. It is required to keep the integrity of fuel rod and assembly until the designed burn up (life limit). If the fuel and cladding temperature are higher than normal temperature, such as in LOCA conditions, hence some phenomenon can be occurred such as degradation of fuel pellet thermal properties, cracking, swelling, strain, pellet-cladding mechanical interaction, etc, as shown in Figure 1 [19, 20].

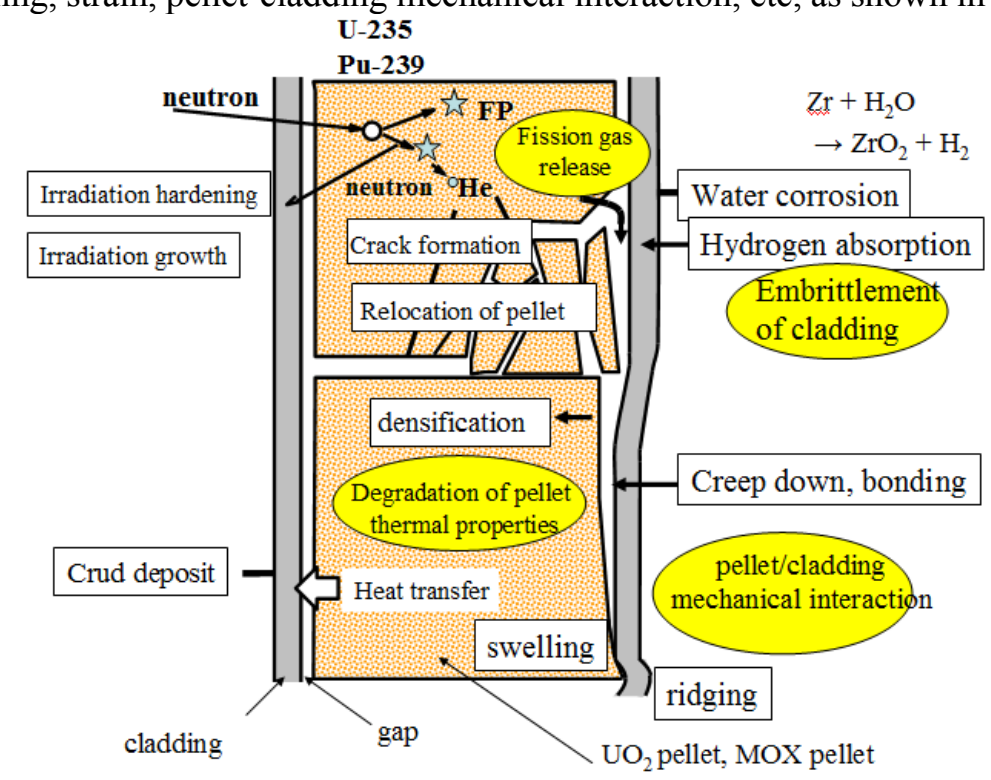

Figure 1. Phenomenon occured when fuel temperature is higher than normal condition during reactor operation [20].

In COBRA-EN code [8], the calculation of the fuel rod temperature distribution is performed by using the CRTN fuel heating model. The model is based on the assumption of no axial and no circumferential heat conduction, and involves correlations for the film, crud, oxide, gap and cladding temperature drops and for the fuel pellet temperature profile. The fuel pellet surface temperature can be written as:

$$
T_{s p}=T_{w}+\Delta T_{f}+\Delta T_{Z r O_{2}}+\Delta T_{\text {clad }}+\Delta T_{g a p}
$$

For forced convection, the temperature drop across the coolant film layer at the surface of the rod is based on the expression:

$$
\Delta T_{f}=q / h_{f}
$$

where $\mathrm{q}$ is the heat flux, given by $\mathrm{Q} /\left(\pi \mathrm{D}_{\mathrm{g}}\right), \mathrm{Q}$ is the linear power density, $\mathrm{D}_{\mathrm{g}}$ is the cladding outer diameter and $h_{f}$ is the film heat transfer coefficient. The film heat transfer coefficient is expressed by Dittus-Boelter as [8]:

$$
h_{f}=\left(0.023 k_{w} / D_{e}\right) \operatorname{Re}^{0.8} \operatorname{Pr}^{0.4}
$$

where:

$\mathrm{k}_{\mathrm{w}}=$ thermal conductivity of coolant (in liquid phase),

$\mathrm{D}_{\mathrm{e}}=$ equivalent diameter of the coolant channel, 
$\operatorname{Re}=$ Reynolds number $\left(D_{\mathrm{e}} \mathrm{G} / \mu\right)$,

$\operatorname{Pr}=$ Prandtl number $\left(\mathrm{C}_{\mathrm{p}} \mu / \mathrm{k}_{\mathrm{W}}\right)$,

$\mathrm{G}=$ flow rate per unit flow area,

$\mathrm{C}_{\mathrm{p}}=$ specific heat of coolant,

$\mu=$ viscosity of coolant.

For fuel rod cladding of zircaloy (such as in PWR type), the temperature drop across the crud and the zirconium oxide (oxide layer) is determined by the expression [8]:

$$
\Delta T_{\mathrm{ZrO}_{2}}=q\left(\frac{\delta_{\text {crud }}}{k_{\text {crud }}}+\frac{\delta_{o x}}{k_{o x}}\right)
$$

where:

$\delta_{\text {crud }}=$ crud thickness,

$\mathrm{k}_{\mathrm{crud}}=$ crud thermal conductivity,

$\delta_{\mathrm{ox}}=$ oxide thickness,

$\mathrm{k}_{\mathrm{OX}}=$ oxide thermal conductivity.

The cladding temperature drop (the difference temperature between outer and inner cladding) is calculated according to the expression [8]:

$$
\Delta T_{\text {clad }}=q \frac{D_{g}}{2 k_{g}} \log \frac{D_{g}}{D_{i g}}
$$

where $\mathrm{D}_{\mathrm{ig}}$ is cladding inner diameter, and $\mathrm{k}_{\mathrm{g}}$ is cladding thermal conductivity.

The temperature drop in the gap (between inner cladding and fuel pellet surface) is determined by the expression [8]:

$$
\Delta T_{\text {gap }}=q / h_{\text {gap }}
$$

where $\mathrm{h}_{\text {gap }}$ is gap heat transfer coefficient. The equation for radial heat conduction in a solid cylindrical pellet can be written as [8]:

$$
\int_{0}^{r} P(r) r d r+r k_{f}(d t / d r)=0
$$

where:

$\mathrm{P}(\mathrm{r})=$ volumetric heat generation rate at the radius $\mathrm{r}$,

$\mathrm{r}=$ radial coordinate,

$\mathrm{T}=$ temperature,

$\mathrm{k}_{\mathrm{f}} \quad=$ pellet thermal conductivity.

\section{METHODOLOGY}

Modeling and calculation to predict fuel temperature due to oxide layer were performed using COBRA-EN code. This analysis used fixed thermal properties of fuel and cladding. The calculation was based on the hot sub-channel. It has peak linear power of $48.88 \mathrm{~kW} / \mathrm{m}$ and the axial power factor $\left(\mathrm{F}_{\mathrm{z}}\right)$ of 1.34 , respectively, at the Beginning of Cycle (BOC) [9].

In modeling the impact of corrosion and crud, a uniform layer of crud and zirconium oxide was added on the inner and outer cladding surface of the hottest rod, as shown in Figure 2. The assumptions that were used in this model as follows:

a. Oxide layer is assumed to be developed first and then a crud layer to be developed on the top of it.

b. The oxide layer and crud occur along the entire height of the hot rod which is unlikely due to the non-uniform axial power profile.

c. The oxide layer and crud occur only on the hot rod 


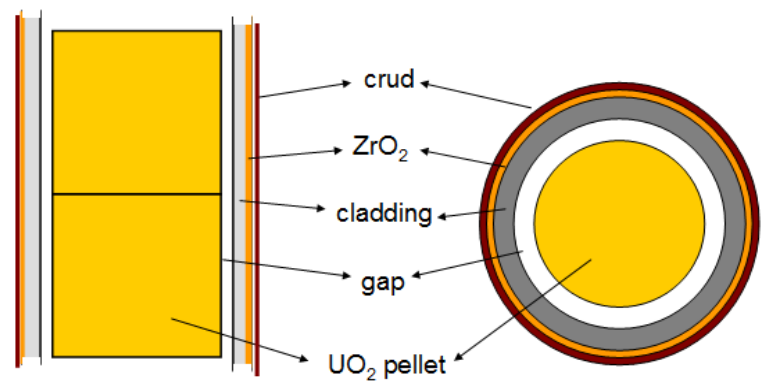

(a)

(b)

Figure 2. Scheme of crud and oxide layer formed on fuel rod (no scale), (a) front view and (b) top view [8].

At the first step, the sub-channel thermal-hydraulics calculation at nominal power and steady state condition were conducted, especially for hot sub-channel which has peak linear power of $48.88 \mathrm{~kW} / \mathrm{m}$. The separate calculations were done for varying thickness of oxide layer (modular oxide) of $0,20,40,60,80,100$ and $120 \mu \mathrm{m}$ and for varying thickness of crud of 0,10 and $20 \mu \mathrm{m}$. The calculations for varying thickness of oxide layer and crud were performed to show that temperature increases from the condition of cladding without oxide layer and crud to the condition of cladding with maximum oxide layer and crud. The calculations were conducted using conservative modular oxide's thermal conductivity of $1.0 \mathrm{~W} / \mathrm{m}^{\circ} \mathrm{C}$ [3] and conservative crud's thermal conductivity of $0.4324 \mathrm{~W} / \mathrm{m}^{\circ} \mathrm{C}$ [7].

At the second step, the calculations for predicting the fuel temperature due to combination of modular oxide layer and crud were compared with the calculation for black oxide layer. The calculations for black oxide layer were done by varying thickness of black oxide layer of $0,10,20$, 30 and $40 \mu \mathrm{m}$ using conservative thermal conductivity of $0.13 \mathrm{~W} / \mathrm{m}^{\circ} \mathrm{C}$ [3]. The varying thickness of black oxide layer was done to show that temperature increases from the condition of cladding without black oxide layer to the condition of cladding with maximum black oxide layer.

\section{RESULTS AND DISCUSSION}

The distribution of center line temperature, radial average fuel temperature and cladding surface temperature of hot sub-channel along the fuel rod length based on the calculation results [9], were shown in Figure 3. Figure 3 shows that the peak fuel center line temperature, the peak radial average fuel temperature and the peak cladding surface temperature are $1608.15^{\circ} \mathrm{C}$, $1126.35^{\circ} \mathrm{C}$, and $348.85^{\circ} \mathrm{C}$, respectively. Moreover, the Minimum Departure from Nucleate Boling Ratio (MDNBR) is 2.49. These calculations were conducted by using COBRA-EN, for hot subchannel without crud and oxide layer on nominal power and steady state condition.

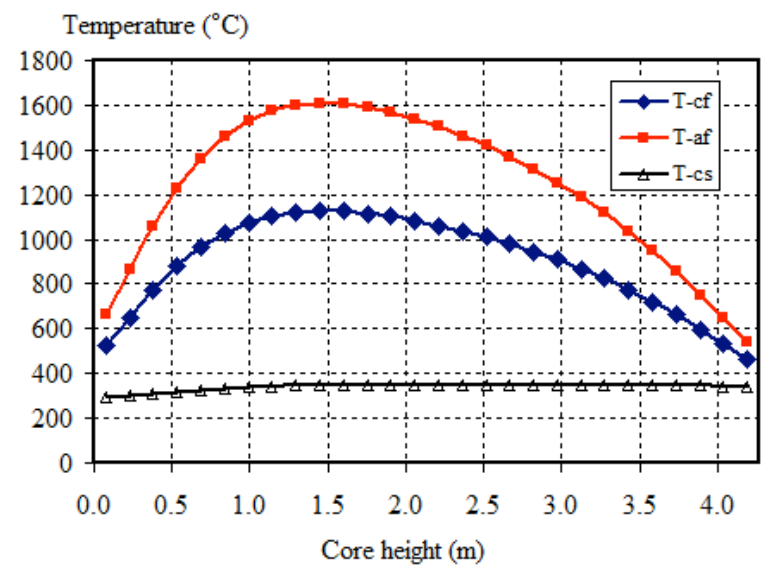

Figure 3. Distribution of center line fuel temperature, radial average fuel temperature and cladding surface temperature of hot sub-channel along the fuel rod length. 
Due to crud and oxide layer were formed on the cladding surface, thus the fuel and cladding temperatures increase, as shown in Figure 4. Figure 4 (a) shows the increasing of peak fuel center line temperature and peak cladding surface temperature as a function of crud thickness. The calculations on the influence of crud thickness variations of 5,10,15 and $20 \mu \mathrm{m}$ give results for the peak fuel center line temperatures of $1626.98^{\circ} \mathrm{C}, 1645.81^{\circ} \mathrm{C}, 1664.63^{\circ} \mathrm{C}$ and $1683.46^{\circ} \mathrm{C}$, respectively. It means that the peak fuel center line temperatures increase by $1.17 \%, 2.34 \%, 3.51 \%$ and $4.68 \%$, respectively, as compared to without crud peak fuel center line temperature of $1608.15^{\circ} \mathrm{C}$. Moreover, the calculations result in the peak cladding surface temperature of $366.03^{\circ} \mathrm{C}$, $384.73^{\circ} \mathrm{C}, 403.50^{\circ} \mathrm{C}$ and $422.26^{\circ} \mathrm{C}$. It means that the peak cladding surface temperatures increase by $5.19 \%, 10.57 \%, 15.96 \%$ and $21.35 \%$, respectively, as compared to without crud peak cladding surface temperature of $347.96^{\circ} \mathrm{C}$.

Temperature $\left({ }^{\circ} \mathrm{C}\right)$

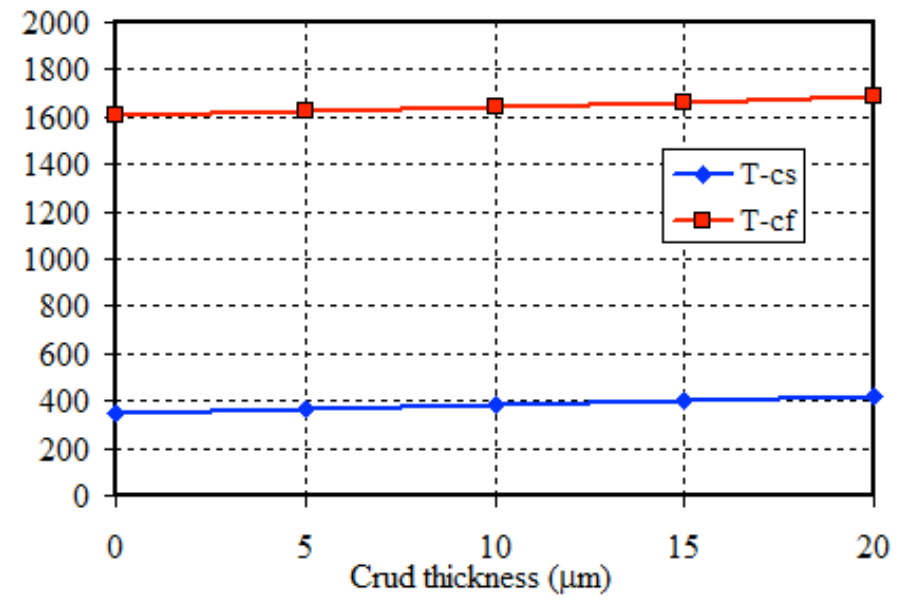

(a)

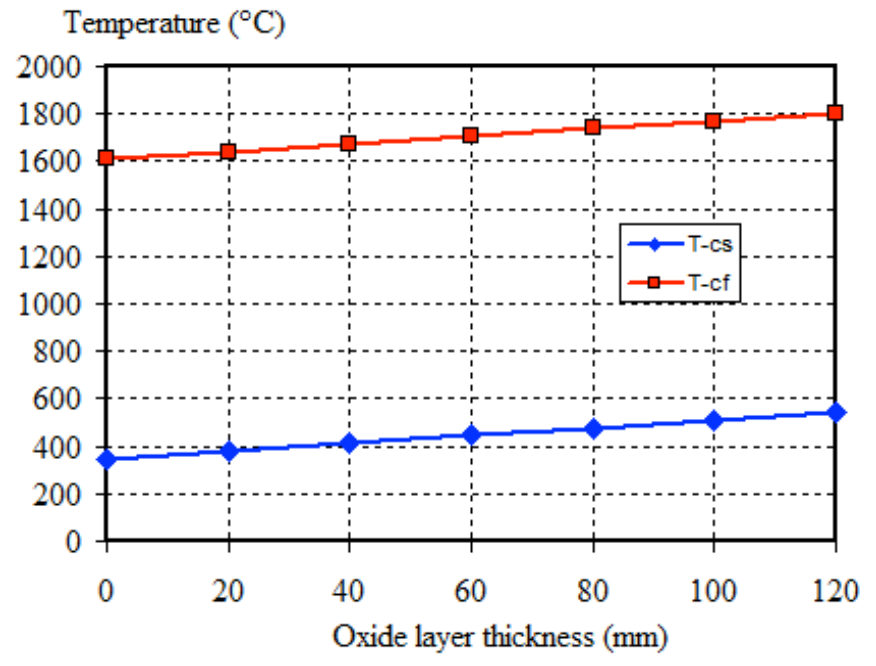

(b)

Figure 4. Graph of peak fuel center line temperature and peak cladding surface temperature as a function of the thickness of (a) crud, and (b) oxide layer

Figure 4 (b) shows the increasing of peak fuel center line temperature and peak cladding surface temperature as a function of oxide layer thickness. The calculations on the influence of oxide layer thickness variations of $20,40,60,80,100$ and $120 \mu \mathrm{m}$ give result for the peak fuel center line temperature of $1640.71^{\circ} \mathrm{C}, 1673.28^{\circ} \mathrm{C}, 1705.85^{\circ} \mathrm{C}, 1738.42^{\circ} \mathrm{C}, 1770.98^{\circ} \mathrm{C}$ and $1803.55^{\circ} \mathrm{C}$, respectively. It means that the peak fuel center line temperatures increase of $2.03 \%$, $4.05 \%, 6.08 \%, 8.10 \%, 10.13 \%$ and $12.15 \%$, respectively, as compared to without crud peak fuel 
center line temperature of $1608.15^{\circ} \mathrm{C}$. Moreover, the calculations result in the peak cladding surface temperature of $379.66^{\circ} \mathrm{C}, 412.11^{\circ} \mathrm{C}, 444.57^{\circ} \mathrm{C}, 477.09^{\circ} \mathrm{C}, 509.65^{\circ} \mathrm{C}$ and $542.22^{\circ} \mathrm{C}$, respectively. It means that the peak cladding surface temperature increase by $9.11 \%, 18.44 \%, 27.76 \%, 37.11 \%$, $46.47 \%$ and $55.83 \%$, respectively, as compared to without crud peak cladding surface temperature of $347.96^{\circ} \mathrm{C}$. Based on Figure 4(b), the maximum of peak fuel center line temperature is $1803.55^{\circ} \mathrm{C}$ and the maximum of peak cladding surface temperature is $542.22^{\circ} \mathrm{C}$, which occur upon $120 \mu \mathrm{m}$ oxide layer on cladding surface.

Figure 5 describes the influence of crud and modular oxide layer combination on cladding surface. The results are also compared with the influence of black oxide layer. The calculations were conducted using combination of crud thickness of 0,10 and $20 \mu \mathrm{m}$ and oxide layer of 0,20 , $40,60,80,100$, and $120 \mu \mathrm{m}$. Whereas the calculations for black oxide layer thickness vary of 0,10 , 20,30 and $40 \mu \mathrm{m}$.

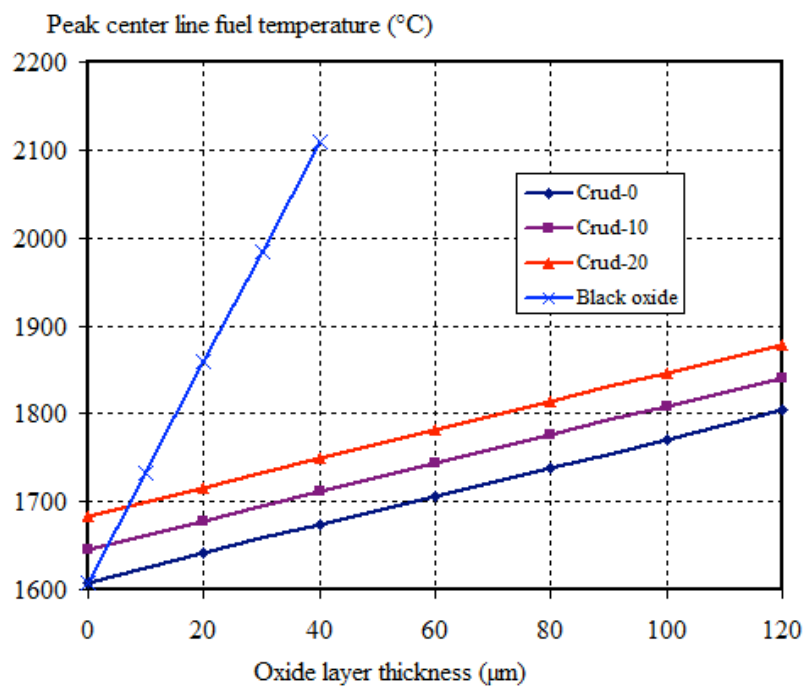

(a)

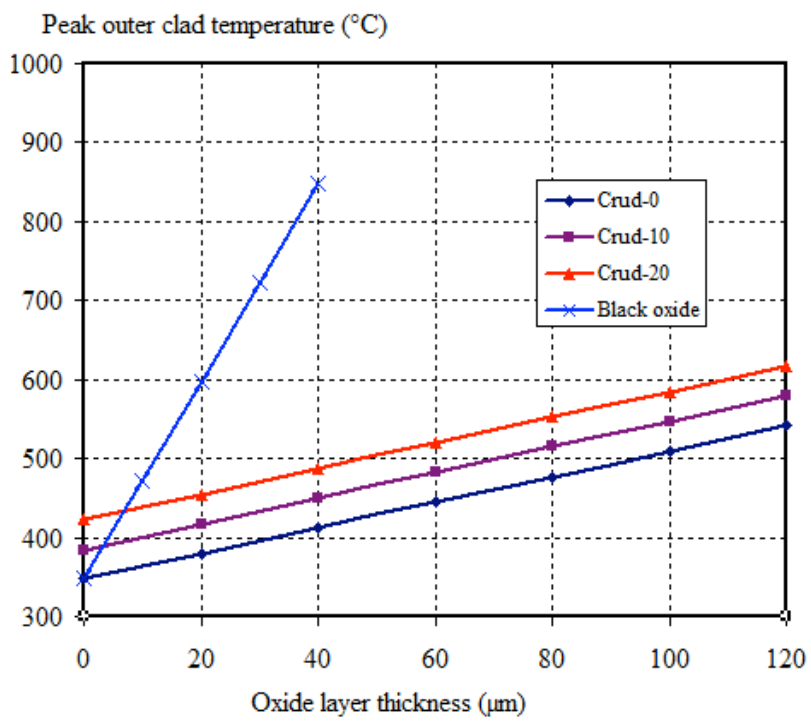

(b)

Figure 5. Comparison between calculation for combination of crud and modular oxide layer and calculation for black oxide layer; (a) peak fuel center line temperature, and (b) peak cladding surface temperature

Figure 5(a) shows that the peak fuel center line temperature for combination of crud thickness of 0,10 and $20 \mu \mathrm{m}$ and without oxide layer are $1608.15^{\circ} \mathrm{C}, 1645.81^{\circ} \mathrm{C}$ and $1683.46^{\circ} \mathrm{C}$, 
respectively. Moreover, the peak fuel center line temperature for combination of crud thickness of 0,10 and $20 \mu \mathrm{m}$ and oxide layer of $120 \mu \mathrm{m}$ are $1803.55^{\circ} \mathrm{C}, 1841.21^{\circ} \mathrm{C}$ and $1878.87^{\circ} \mathrm{C}$, respectively. Whereas, the peak fuel center line temperature for condition without black oxide layer is $1608.15^{\circ} \mathrm{C}$, and the temperature for oxide layer condition of $40 \mu \mathrm{m}$ was $2109.19^{\circ} \mathrm{C}$, respectively. The black oxide layer has $12.25 \%$ of fuel temperature higher than the highest fuel temperature of combination model. It is caused by the black oxide layer's thermal conductivity of $0.13 \mathrm{~W} / \mathrm{m}^{\circ} \mathrm{C}$ less than thermal conductivity of combination model of crud and oxide layer.

Figure 5(b) shows that the peak cladding surface temperature for combination of crud thickness of 0,10 and $20 \mu \mathrm{m}$ and without oxide layer are $347.96^{\circ} \mathrm{C}, 384.73^{\circ} \mathrm{C}$ and $422.26^{\circ} \mathrm{C}$, respectively. Moreover, that the peak cladding surface temperature for combination of crud thickness of 0,10 and $20 \mu \mathrm{m}$ and oxide layer of $120 \mu \mathrm{m}$ are $542.22^{\circ} \mathrm{C}, 579.88^{\circ} \mathrm{C}$ and $617.54^{\circ} \mathrm{C}$, respectively. Whereas, the peak cladding surface temperature for condition of without black oxide layer is $347.96^{\circ} \mathrm{C}$, and the temperature for condition of oxide layer of $40 \mu \mathrm{m}$ is $847.86^{\circ} \mathrm{C}$, respectively. The black oxide layer has $37.30 \%$ of cladding surface temperature higher than the highest cladding surface temperature of combination model.

For full cycle hot sub-channel condition, the combination of crud thickness of $20 \mu \mathrm{m}$ and modular oxide thickness of $115 \mu \mathrm{m}$ give prediction for the peak fuel center line temperature and the peak cladding surface temperature of $1870.73^{\circ} \mathrm{C}$ and $609.40^{\circ} \mathrm{C}$, respectively. Whereas, for black oxide thickness of $20 \mu \mathrm{m}$ gives prediction for the peak fuel center line temperature and the peak cladding surface temperature of $1858.57^{\circ} \mathrm{C}$ and $597.34^{\circ} \mathrm{C}$, respectively. The results show that peak fuel center line temperature and the peak cladding surface temperature deviation are $-1.98 \%$ and $0.64 \%$, respectively.

The power peaking factor in AP1000 operation cycle divided into 3 sub cycles, i.e., beginning of cycle (BOC), middle of cycle (MOC) and end of cycle (EOC) [9]. By using conservative assumption, the BOC takes place at $40 \%$ of full cycle. Therefore, the realistic of crud thickness is $8 \mu \mathrm{m}$, the modular oxide is $46 \mu \mathrm{m}$ and the black oxide thickness is $8 \mu \mathrm{m}$, respectively. For the combination of crud thickness of $8 \mu \mathrm{m}$ and modular oxide thickness of $46 \mu \mathrm{m}$, the conservative prediction of the peak fuel center line temperature and the peak cladding surface temperature were $1713.18^{\circ} \mathrm{C}$ and $451.87^{\circ} \mathrm{C}$, respectively. Whereas, for $8 \mu \mathrm{m}$ of black oxide thickness, the prediction of the peak fuel center line temperature and the peak cladding surface temperature are $1708.35^{\circ} \mathrm{C}$ and $447.06^{\circ} \mathrm{C}$, respectively. The results show that deviation of peak fuel center line temperature and the peak cladding surface temperature are $-1.06 \%$ and $-0.28 \%$, respectively. By using conservative prediction, the peak fuel center line temperature and the peak cladding surface temperature increase of $6.53 \%$ and $29.86 \%$ as compared with the temperature of normal and fresh condition, respectively.

\section{CONCLUSION}

An analysis to predict fuel and cladding temperature due to crud and oxide layer has been carried out. The effect of an oxide layer and crud formed on the cladding surface, decreases the total heat transfer from the cladding to the coolant. Consequently, the fuel and cladding temperatures increase. The analysis was conducted for nominal power using COBRA-EN code, by varying modular oxide layer thickness of $0-120 \mu \mathrm{m}$ and crud thickness of $0-20 \mu \mathrm{m}$, and compared with black oxide thickness variations of $0-20 \mu \mathrm{m}$. The oxide layer is predicted only formed on hot sub-channel during BOC ( $40 \%$ of full cycle). The results show that the prediction of the peak fuel center line temperature and the peak cladding surface temperature are $1713.18^{\circ} \mathrm{C}$ and $451.87^{\circ} \mathrm{C}$, respectively. Compared to the normal and fresh fuel conditions, the peak fuel center line temperature and the peak cladding surface temperature increase by $6.53 \%$ and $29.86 \%$, respectively. 


\section{ACKNOWLEDGEMENT}

The authors would like to thank to JAEA Expert, Dr. Jinichi Nakamura, for his permission to use the material course. This research was funded by Center for Nuclear Reactor Technology and Safety in BATAN's DIPA 2016/ Number: SP DIPA 080.01.1.450310/2016.

\section{REFFERENCES}

1. Kim J.S., Kim Y.S. Effect of Thermal History on the Termonal Solid Solubility of Hydrogen in Zircaloy-4. International Journal of Hydrogen Energy 2014; 39: 1642216449 .

2. Buongiorno J. Can Corrosion and CRUD actually improve safety margin in LWRs? Annals of Nuclear Energy 2014; 63: 9-21.

3. Siefken L.J., Coryell E.W., Harvego E.A., Hohorst J.K. MATPRO - A Library of Material Properties for Light Water Reactor Accident Analysis. NUREG/CR-6159. Vol 4. Rev. 2. Chapter 5. 2001. p.1-15.

4. Lee Y., Lee J.I., No H.C. Impacts of Transients Heat Transfer Modeling on Prediction of Advanced Cladding Fracture During LWR LBLOCA. Nuclear Engineering and Design 2016; 298: 25-32.

5. Zhang L., Bao Y., Tang R. Selection and corrosion evaluation tests of candidate SCWR fuel cladding materials. Nuclear Engineering and Design 2012; 249: 180-187.

6. Jin H.J., Kim T.K. Neutron irradiation performance of Zircaloy-4 under research reactor operating conditions. Annals of Nuclear Energy 2015; 75: 309-315.

7. Lee J.S., Shin A., Kang S.S., Woo S.W. Assessment of Fuel Rod Performance by Consideration of Crud Deposition. Transaction of the Korean Nuclear Society Spring Meeting. Gyeongju, Korea, May 29-30, 2008.p.245-246.

8. Basile D., Behgi M., Chierici R., Salina E., Brega E., "COBRA-EN : Code System for Thermal-Hydraulic Transient Analysis of Light Water Reactor Fuel Assemblies and Cores", RSICC Code Package PSR-507, May, Oak-Ridge (2001)

9. Isnaini, M.D., Widodo S., Subekti M.. Thermal-Hydraulics Analysis on Radial and Axial Power Fluctuation for AP1000 Reactor. Tri Dasa Mega 2015; 17(2): 79-86.

10. Isnaini M.D., Mutiara E., A Comparison in Thermal-Hydraulics Analisys of PWR-1000 using fixed and temperature function of thermal conductivity. Jurnal Pengembangan Energi Nuklir 2016;18(1): 31-38.

11. Isnaini M.D., Subekti M.Validation of SIMBAT-PWR Using Standard Code COBRA-EN on Reactor Transient Condition. Tri Dasa Mega 2016; 18(1): 41-50.

12. Rahgoshay M., Tilehnoee M.H. Optimizing a gap conductance model applicable to VVER-1000 thermal-hydraulic model. Annals of Nuclear Energy 2012;50: 263-267.

13. Aghaie M., Zolfaghari A., Minuchehr M., Norouzi A. Enhancement of COBRA-EN capability for VVER reactors calculations. Annals of Nuclear Energy 2012;46: 234-243.

14. Rahmani Y., Pazirandeh A., Ghofrani M.B., Sadighi M. Calculation of the Deterministic Optimum Loading Pattern of the BUSHEHR VVER-1000 Reactor Using the Weighting Factor Method. Annals of Nuclear Energy 2012;49: 170-181.

15. Rahimi M.H., Jahanfaria G. Thermal-Hydraulic Core Analysis of the VVER-1000 Reactor Using Porous Media Approach. Journal of Fluids and Structures 2014;51: 85-96.

16. Zarifi E., Jahanfarnia G., Veysi F., "Sub-channel Analysis of Nanofluids Application to VVER-1000 Reactor. Chemical Engineering Research and Design 2013; 91: 625-632.

17. Suman S., Khan M.K., Pathak M., Singh R.N., Chakravartty J.K. Rupture behaviour of nuclear fuel cladding during loss of coolant accident. Nuclear Engineering and Design 2016; 307: 319-327.

18. Pshenichnikov A., Stuckert J., Walter M. Microstructure and Mecahinal Properties of Zircaloy-4 Cladding hydrogenated at temperatures typical for loss-of-coolant accident (LOCA) conditions. Nuclear Engineering and Design 2015; 283: 33-39. 
19. Wu H., Udagawa Y., Narukawa T., Amaya M. Crack formation in cladding under LOCA quench conditions. Nuclear Engineering and Design 2016; 303: 25-30.

20. Nakamura J. Nuclear Fuel Engineering. Reactor Engineering, International Training Course. Japan Atomic Energy Agency, September 2014. 